\title{
Improving undergraduate medical student involvement in research
}

This article was published in the following Dove Press journal:

Advances in Medical Education and Practice

3 November 2017

Number of times this article has been viewed

\section{Fatima Yussuf \\ Katerina Fernandova \\ Huda Khalif}

Faculty of Medicine, St George's Hospital Medical School, London, UK
Correspondence: Fatima Yussuf Faculty of Medicine, St George's Hospital Medical School, Cranmer Terrace, London, SWI7 ORE, UK

Tel +44776605 7282

Email fatimayussuf@live.com

\section{Dear editor}

We read with great interest the article by Abulaban et al ${ }^{1}$ on the opinions about research held by medical students in Saudi Arabia. As final-year medical students at one of the best-ranked universities for its research influence, we would like to offer our views and experiences in regard to participating in research.

It is evident that medical students in both Saudi Arabia and the UK are aware of the usefulness of participating in research, with $90 \%$ of students in Abulaban et al's study and $86 \%$ of students from a UK medical school recognizing its importance. ${ }^{1,2} \mathrm{~A}$ common motivation for participating in research among medical students is the beneficial impact it can have on career progression in both Saudi Arabia and the UK. ${ }^{1-3}$ Despite this drive, less than half of students get involved with research. This is demonstrated in a study similar to that of Abulaban et al, conducted in seven medical schools in the UK where only $49 \%$ of students had participated in research. ${ }^{1,3}$

In the UK, the importance of research is reflected in the Foundation Programme junior doctor applications where additional points are awarded for publications. Despite this, only $59 \%$ of medical students across seven medical schools were aware that publishing research was an awarded criterion. ${ }^{3}$

A gap has been shown in research opportunities for medical students despite there being motivation to get involved. Thus, it is important that solutions are identified. Research has shown that some of the reasons why students do not participate are time constraints and lack of opportunities and encouragement from supervisors. ${ }^{2,3}$ We agree with the solutions presented by Abulaban et al and would like to propose some further points.

One barrier raised by UK medical students was the lack of supervisor support; this can be resolved by appointing dedicated supervisors for medical students to utilize throughout their degree. As medical students, we are often unaware of the range of research opportunities available to us. This could be improved by creating a platform to display current research opportunities, for example a forum on the university website. Finally, the issue of time constraints can be improved by making medical students aware of research and its importance earlier on in their education. A study has shown that $71 \%$ of students who publish research are either final-year medical students or those doing an intercalated degree. ${ }^{3}$ Personally, we were unaware of the importance of research until later on in our medical education and during our intercalated degrees. Although most UK medical schools incorporate a student-selected component into the curriculum, we have not found it sufficient enough for conducting publishable submit your manuscript Dovepress if in $D$ http://dx.doi.org/10.2147/AMEP.SI504 
research. One way of overcoming this issue is by formally incorporating research-focused time into the curriculum. This initiative has already been implemented in some European countries, such as the Netherlands. ${ }^{4}$

Research is a key element in the progression of medicine; thus, to permit future doctors to engage in research, we must provide the medical students of today with the correct skills, experiences and opportunities.

\section{Disclosure}

The authors report no conflicts of interest in this communication.

\section{References}

1. Abulaban A, Alharbi A, BinDajam O, et al. Changing opinions about research by Saudi medical students. Adv Med Educ Pract. 2017;8:571-575.

2. Nikkar-Esfahani A, Jamjoom AA, Fitzgerald JE. Extracurricular participation in research and audit by medical students: opportunities, obstacles, motivation and outcomes. Med Teach. 2012;34(5):e317-e324.

3. Griffin MF, Hindocha S. Publication practices of medical students at British medical schools: experience, attitudes and barriers to publish. Med Teach. 2011;33(1):e1-e8.

4. Burgoyne LN, O'Flynn S, Boylan GB. Undergraduate medical research: the student perspective. Med Educ Online. 2010;15:5212. 


\section{Authors' reply}

\section{Ahmad Abulaban \\ Abdulla Al Sayyari}

Department of Medicine, Division of Neurology, King Saud bin Abdulaziz University for Health Sciences, King Abdulaziz Medical City, National Guard Health Affairs, Riyadh, Saudi Arabia

Correspondence: Ahmad Abulaban

Department of Medicine, Division of Neurology, King Saud bin Abdulaziz University for Health Sciences, King Abdulaziz Medical City, National Guard Health Affairs, PO Box 22490, Riyadh I 1426, Saudi Arabia Tel +966 I I80 I I I I I (ext I3450)

Email neuroahmad@yahoo.com

\section{Dear editor}

The letter by Yussuf et al is very instructive and thoughtful. It carries special significance as it is written by people directly involved, namely, medical students.
Their comments confirm a number of the findings in our paper and highlight similar hurdles and potential solutions that would apply to both Saudi Arabia and the UK and elsewhere.

The additional proposed solutions in their letter are excellent and worth implementing. In our university (King Saud bin Abdulaziz University for Health Sciences), completing a research project is obligatory for all medical students before they can be allowed to graduate.

\section{Disclosure}

The authors report no conflicts of interest in this communication.

Dove Medical Press encourages responsible, free and frank academic debate. The content of the Advances in Medical Education and Practice 'letters to the editor' section does not necessarily represent the views of Dove Medical Press, its officers, agents, employees, related entities or the Advances in Medical Education and Practice editors. While all reasonable steps have been taken to confirm the content of each letter, Dove Medical Press accepts no liability in respect of the content of any letter, nor is it responsible for the content and accuracy of any letter to the editor.

\section{Publish your work in this journal}

Advances in Medical Education and Practice is an international, peerreviewed, open access journal that aims to present and publish research on Medical Education covering medical, dental, nursing and allied health care professional education. The journal covers undergraduate education, postgraduate training and continuing medical education including emerging trends and innovative models linking education, research, and health care services. The manuscript management system is completely online and includes a very quick and fair peer-review system. Visit http://www.dovepress.com/testimonials.php to read real quotes from published authors.

Submit your manuscript here: http://www.dovepress.com/advances-in-medical-education-and-practice-journal 